News Values Revisited: A Comparison between Citizen and Mainstream Media in Hong Kong \author{
Chun Hong Tse ${ }^{1}$, Roberto Spiezio ${ }^{2}$ \\ ${ }^{1}$ School of Journalism and Communication, The Chinese University of Hong Kong \\ ${ }^{2}$ International College, Ming Chuan University
}

\begin{abstract}
Author Details
Chun Hong Tse is a master's student at the School of Journalism and Communication, The Chinese University of Hong Kong. His research interests focus on journalism with a particular emphasis on citizen journalism, computer-mediated communication, and political communication.

Email: 1155163595@link.cuhk.edu.hk/ chtse26-c@my.cityu.edu.hk ORCID: 0000-0002-8549-928X

Roberto Spiezio is Assistant Professor at the International College, Journalism and Mass Communication Program, Ming Chuan University, Taiwan. His research interests include comparative media representation of socio-cultural phenomena, health communication, and citizen journalism.

Email: rspiezio@mail.mcu.edu.tw
\end{abstract}

ORCID: 0000-0002-9008-6340 
This is a pre-print version of the following article to appear in Journalism Practice:

Tse, C. H., \& Spiezio, R. (2022). News Values Revisited: A Comparison between Citizen and Mainstream Media in Hong Kong. Journalism Practice. https://doi.org/10.1080/17512786.2022.2145339

\section{Acknowledgements}

We would like to thank Tetsuro Kobayashi, Michael Prieler, and the reviewers for their precious and constructive feedback. We are especially grateful to our research assistant, Wyman Lee, for his contribution to the coding process. 


\title{
News Values Revisited: A Comparison between Citizen and Mainstream Media in Hong
}

\section{Kong}

\begin{abstract}
News values is a research topic that has received extensive attention in the scholarship. However, previous studies have not widely examined news values in the context of Citizen Journalism. Drawing on Harcup \& O'Neill's $(2001 ; 2017)$ contemporary news values model, this study employs a content analysis of 420 Citizen Journalism and mainstream news lead articles in Hong Kong media, collected respectively from the local outlets StandNews and MingPao.

The results show that Citizen Journalism publication StandNews tends to adopt and make similar use of news values to the mainstream MingPao in publishing its articles, which suggests that in Hong Kong, Citizen Journalism is increasingly closing the gap with mainstream media in terms of the editorial decisions that lead to the publication of news stories and, more in general, in terms of newsworthiness. This study intends to contribute to the comprehension of how news values compare between Citizen Journalism and mainstream news outlets, and therefore whether Citizen Journalism presents traits of newsworthiness.
\end{abstract}

Keywords: News Values, Journalism, Mainstream Media, Citizen Media, Content Analysis, News 


\section{News Values Revisited: A Comparison between Citizen and Mainstream Media in Hong}

\section{Kong}

News values - defined as essential considerations of the criteria in the worthiness of being published as news (Caple \& Bednarek, 2016, p. 436) —is a research topic that has received extensive attention across the globe, for example, in the United Kingdom (Harcup \& O'Neill, 2001; 2017), the United States (Schaudt \& Carpenter, 2009), and the Netherlands (Burggraaff \& Trilling, 2020). These studies typically focus on traditional or mainstream news outlets. With the rise of Citizen Journalism since the early 2000s, individuals have been empowered to gather, produce, and publish news content (Nip, 2016). However, previous studies have not widely examined news values in the context of Citizen Journalism.

Drawing on the contemporary news values model introduced by Harcup \& O'Neill (2017), this study consists of two content analyses of the news values underlying the publication of Citizen Journalism and mainstream news outlets' articles. The comparison of news values between mainstream and citizen media intends to foster better understanding of the topic of Citizen Journalism, to comprehend the difference between the news values in Citizen Journalism and mainstream media outlets, and therefore whether Citizen Journalism presents traits of newsworthiness. The results show that Citizen Journalism publication StandNews tends to adopt and make similar use of news values to the mainstream MingPao in publishing its articles, which suggests that in Hong Kong, Citizen Journalism is increasingly closing the gap with mainstream media in terms of newsworthiness.

This under-researched area of the scholarship bears several implications. Firstly, news values are a key aspect to understand for new journalism students and other parties, such as public relations professionals, contributing to rendering news selection a more transparent and 
better-understood process. Secondly, it guides readers to understand which news values could be considered exclusive to mainstream media organizations and their rationales.

\section{Literature Review}

\section{Contemporary News Values}

This study emphasizes the concept of news values. Galtung and Ruge (1965) set up the foundations for the subsequent scholarship on the topic in their seminal study. Several news factors are relevant in selection, distortion and replication during news communication. Through a content analysis on four Norwegian news and three international crises papers, the identified news criteria included Frequency, Threshold, Absolute Intensity, Intensity Increase, Unambiguity, Meaningfulness, Cultural Proximity, Relevance, Consonance, Predictability, Demand, Unexpectedness, Unpredictability, Scarcity, Continuity Composition, and references to Elite Nations. Research on news values implies answering a fundamental question:"What is news?". Galtung and Ruge's (1965) study served as the "theoretical and methodological backbone" towards news values research (e.g., Eilders, 1997; 2006, p.6, Schulz, 1982). News values have received extensive attention in Journalism and Communication-related disciplines, and studies have been carried out across several places in the western world, including the Netherlands (e.g., Welbers et al. 2016), Sweden (e.g., Westerståhl \& Johansson, 1994), the United Kingdom (e.g., Lewis, Williams \& Franklin, 2008; Harcup \& O’Neill, 2001; 2017) and Norway (e.g., Galtung \& Ruge, 1965) among others. An examination of the literature indicated that content analysis (e.g., Galtung \& Ruge, 1965; Harcup \& O’Neill, 2001; 2017), interviews (e.g., Dick, 2014), and questionnaires (e.g., Lavie \& Lehman-Wilzig, 2003) were the most common methods employed in researching news values. 
One of the common criticisms towards the original study on news values is that Galtung and Ruge focused on the textual part, while visuals, such as photos, videos, and infographics, were not covered (Caple \& Bednarek, 2016; Dick, 2014). Interactive infographics are considered increasingly critical in contemporary journalistic education. Caple and Bednarek (2016) extended the literature by suggesting a discursive approach that argued photos could show news values, including superlativeness, negativity, personalization, and aesthetic appeal. Apart from the standard values, drama also plays a role (Westerståhl \& Johansson, 1994). O'Neill (2012) paid attention specifically to celebrity news by carrying out content analyses of how the newspapers The Guardian, The Times, and The Daily Telegraph covered two celebrity deaths: Elvis Presley and Michael Jackson. The paper showed that the news coverage of celebrities, Surprise, and Bad News had increased in the past 30 years. The news values can be narrowed down to six dominant news values: Timeliness, Relevance, Identification, Conflict, Sensation, and Exclusivity. A clear distinction could be drawn between orthodox news values and heterodox news values, in other words, hard news and soft news (Schultz, 2007).

From a psychological perspective, social validation of judgments and stabilizing existing attitudes and cognitions of the journalists also affect news selection decisions (Donsbach, 2004). Lavie and Lehman-Wilzig (2003) showed no significant gender differences among editors in selecting the news. Journalists are considered the fourth estate and have journalistic independence. Apart from directly selecting the news, journalists rely on various sources, including public relations professionals and news agencies, during the news gathering process. Therefore, it is suggested that fact-checking and critically evaluating the source are essential aspects of journalism practice (Lewis, Williams \& Franklin, 2008). 
The previous discussion of the literature indicates that several factors affect the news selection process, not only the significance of news events as suggested by Galtung and Ruge (1965), but also use of images and infographics, and psychological factors about journalists.

Harcup and O'Neill $(2001 ; 2017)$ extended the Galtung and Ruge (1965) findings to a contemporary perspective. They argued that Galtung and Ruge's work failed to identify the news values for most news articles, and some news values may not apply to the contemporary situation. They also questioned the view of putting the Galtung and Ruge (1965) model as the backbone of study and maintained that the model should be opened for questioning instead. Therefore, an updated list of news values was needed. Content analysis was used to understand the factors of selecting news events from the three widely read newspapers in the United Kingdom, namely the Sun, Daily Mail, and Daily Telegraph, in March 1999. The contemporary news values included Power Elite, Celebrity, Entertainment, Surprise, Bad News, Good News, Magnitude, Relevance, Follow-up, and newspaper Agenda.

News values have changed in the digital age. Journalists use tools to monitor the audience clicks on news websites, showing that audience clicks influenced journalists' decision to select news and reaffirming that proximity and importance are the two most relevant factors in news consideration (Welbers et al. 2016). The social media platforms provide new opportunities for journalists to reach more readers - Hermida (2010) calls it "ambient journalism"- by engaging the audience to share, like, and interact with others without the time constraint (Al-Rawi, 2017). Harcup and O'Neill's (2001) study was revisited in 2017, while the attention was put on the emergence of social media. They found that Shareability received more and more attention alongside the clicks and shares of the online news. Moreover, their study integrated the views of previous works, for example, the importance of Audiovisuals that was considered a vital factor, 
especially for the online news by scholars including Caple and Bednarek (2015), and Dick

(2014). From the methodological perspective, the study extended the scope of their study to 10 newspapers in the United Kingdom and accessed the top 10 Facebook and top 15 most shared news articles on Twitter, finding similarities and differences between social media and print news. For example, in print news, the most common news value is Bad News, whereas, in social media, the most common news value is Entertainment. In contrast with their work conducted in 2001, Exclusivity, Conflict, Surprise, Audiovisuals, Shareability, Drama were the newly added news values, contributing to a list of 15 contemporary sets of news values in total. Nonetheless, what the studies have in common is that they both agreed that Conflict and Exclusivity are the most critical factors influencing the decision in considering what news to select and the treatment process.

In literature there have been few discussions on how non-elite actors make the news and constitute criteria for publishing information when they become the direct protagonists of news events. Caple and Bednarek's study (2016) and Bednarek and Caple's book (2017) on theorizing news values in a discursive context mention "personalization" as a news value. Personalization refers to "a particular news value, which concerns references to 'ordinary' people (eyewitnesses, survivors, or other private citizens), that is, references to non-elite individuals not acting or speaking in an official capacity. This explicitly excludes references to elite news actors, unless they are represented as not acting in their elite capacity or as speaking on behalf of ordinary people.” (Bednarek \& Caple, 2017, p.62). This study on one hand acknowledges the importance of the previously mentioned news value in any discussion on news values, and on the other hand, it builds upon, extends, and refocuses Personalization as theorized by the two authors by introducing and investigating a news value we called Common Man. The rationale for focusing 
on Common Man as one of the analyzed news values lies in the fact that citizen journalism outlets routinely publish articles written by non-professionals, common people indeed, who may be more sensitive to how life events involve them in different ways. Making a comparison between citizen journalism and mainstream media, an investigation into the two sides of the coin, Power Elite and Common Man, seems therefore reasonable. As previously mentioned, Common Man, as conceptualized in this study, both refocuses and extends the concept of Personalization. Similarly to Personalization, Common Man involves non-elites, but it does not merely look at "references to ordinary people" as emerging from the news discourse (Bednarek \& Caple, 2017, p.62). It indeed regards non-elite actors as opposed to power elite actors, and it includes not only the role of common people as "witnesses, survivors or other private citizens" (Bednarek \& Caple, 2017, p.62), but more explicitly non-elites as the protagonists of the story, common people as actors other than mere re-actors, common people as the focus of the stories.

Without a doubt, current news value studies show that the western conceptualization of news values is the most dominant, with little attention paid to the Asian context. Several scholars rewrote the news values to fit better the Asian context (e.g., Peterson, 1992; Sobhan, 1981). In Hong Kong, for example, Chu (2011) conducted interviews with journalist bloggers and discovered that journalists struggled to balance news values and workplace rules given the complicated context, but they still used journalist blogs to share their professional lives and ideological beliefs. Lee (2010) discovered that resource allocation is an essential factor influencing election news production in Hong Kong in addition to news values. Nonetheless, because the studies were conducted at least ten years ago, these values have not corresponded to the contemporary Asian context. Therefore, an updated contemporary examination of news values in the Asian context is required. On the other hand, there are currently no news values 
studies focusing on citizen media in Hong Kong. An empirical study examining alternative media values is needed.

\section{News values of Citizen Journalism}

Citizen Journalism is commonly referred to as grassroots journalism, participatory journalism, community journalism among other expressions. There have been several scholars attempting to give definitions of this concept. Nonetheless, no consensus has been reached (Kim \& Lowrey, 2015). In an earlier stage, researchers such as Bowman and Willis (2003) defined this concept as "The act of a citizen, or group of citizens, playing an active role in the process of collecting, reporting, analyzing, and disseminating news and information. This participation intends to provide the independent, reliable, accurate, and wide-ranging and relevant information that a democracy requires." (p.9). This conceptualization method stresses the function of Citizen Journalism and implies that it considered Citizen Journalism as news. Carpenter (2010b) counts citizen journalists as individuals who intend to publish beneficial information. Wall (2015) emphasized the news content, arguing that Citizen Journalism is considered made by non-professional people producing text, video, audio, or other interactive materials. In general, they are considered people without organizational ties and unprofessional. Paul (2017) conceptualized citizen journalists as people who contribute news content on a public website, while Nah and Chung (2016) argued that citizen journalists are people who submitted an article on a Citizen Journalism website. OhmyNews, founded by journalist and technology entrepreneur Oh Yeon Ho, was a popular Korean Citizen Journalism platform during the early-mid 2000s.

Carpenter (2008) showed that citizen journalists and professional journalists write different news types by carrying a content analysis of Citizen Journalism and mainstream newspapers in the United States. This study has shown that professional journalists wrote articles 
on a more significant proportion of official, organizational, and male sources instead of opinions raised by themselves. Online Citizen Journalism articles were more likely to feature a greater diversity of information than traditional online journalism sites (Carpenter, 2010b). This study focuses on the content and topics only, and the selection criteria are not covered. Schaud and Carpenter (2009) conducted another content analysis to analyze the news values in the most-viewed stories on The Arizona Republic's 15 community websites. They revealed that crime, business, soft news, and political stories were most likely to be clicked. Readers tended to prefer stories with high Proximity and Conflict instead of Timeliness and Prominence, which were least preferred. They then found that the preferable ranking is associated with audience selection to the story. However, the study was conducted in 2009 , while they adopted the Schultz (2007) six news values model, including Conflict, Human Interest, Magnitude, Prominence, Proximity, Tragedy, and Timeliness. This study follows instead Harcup and O'Neill's (2017) model set of news values to examine the news values, since it provides the latest enhancement of the news values model and a comprehensive view, compared with Schultz's (2007) six common news values model.

\section{Research Context and Questions}

This study chose Hong Kong's media environment for analysis. There were not many studies about Citizen Journalism in this area. Further studies can lead us to a better understanding of the phenomenon in this place. Stand News and Hong Kong Free Press are salient examples that show a combination of professional and Citizen Journalism.

This research compares the contemporary news values model by carrying out a content analysis of articles written by Citizen Journalism and mainstream media outlets, to investigate whether the values differ between the two. This study focuses on two aspects of news values. 
Firstly, the paper intends to explore the differences in news values between articles written by mainstream news outlets and citizen journalists. Secondly, it examines the differences in critical news values between mainstream and Citizen Journalism outlets. Therefore, two research questions can preliminarily be posed:

RQ1. To what extent is the difference in news values between articles written by mainstream news outlets and citizen journalists?

RQ2. Are there any exclusive news values that could only be found in Citizen Journalism news?

\section{Method}

What follows is a discussion of the specific method used to investigate and possibly answer the Research Questions related to how news values compare in mainstream and citizen media outlets in Hong Kong. This study comparatively analyzes the news values as criteria of the publication of articles on two Hong Kong outlets in Cantonese Chinese language, the mainstream media newspaper MingPao, and the citizen media outlet StandNews.

Mingpao, which was founded in May 1959, is one of Hong Kong's leading mainstream Chinese newspaper agencies. In general, it does not exhibit a specific political preference in its news writing style. A wide range of topics are covered, including not only hard news such as political news, Hong Kong news, and international news, but also soft news such as entertainment and sports.

Founded in December 2014, Standnews is a free, non-profit news outlet based in Hong Kong, it is widely regarded as a pan-democratic newspaper in the city. In contrast to Mingpao, Standnews solely publishes web news and does not distribute hard copies. As of June 2019, there were 21 full-time staff and numerous bloggers were submitting articles, generating millions of 
pages views a day. Thus, it was considered a publication at the highest credibility levels among online news outlets in Hong Kong, according to a Chinese University of Hong Kong survey in 2019 (Centre for Communication and Public Opinion Survey, 2019). Given that its business model is similar to that of OhmyNews, which has a floating staff of over 80000 citizen journalists and 100 full-time staff (Kang, 2016), we considered Standnews as a Citizen Journalism outlet in Hong Kong.

In longitudinal terms, the analysis encompasses the period between January 2018 and December 2020 to detect changes over time. While MingPao also has a chartaceous edition, StandNews only has an online version. For analytical and practical purposes, therefore, the examination focused on the online versions of both publications. In terms of methods, this study employed content analysis, a well-established method of choice in media analysis and news coverage investigations, as the broad scholarship available shows (e.g., Avila, 2009; Burris, 1999; Bird, 2005; Culig, 2012; Duchscher, 1998; Li \& Izard, 2003), in order to examine the characteristics of the news coverage in the selected publications and to identify the news values that may underlie the publication of the sampled articles, allowing in this way a comparison between the outlets. A quantitative content analysis has been chosen as the method of analysis in the light of pre-existing literature upon which this study builds, in particular Harcup and O'Neill's studies (e.g., 2017) related to the identification of news values in the United Kingdom. To answer the research questions, which involve ranking and comparing the news values, a quantitative approach seems therefore appropriate. However, a quantitative approach would only provide a broad and general picture on the news values and does not exclude a further qualitative study. A qualitative study is in fact complementary to this study and necessary to delve into the 
data gathered and to look at the details, answering specific RQs on how the news values compare in specific situations/events/articles both within and across publications.

\section{Population and Sample}

The analysis of the news coverage and the detection of the related news values in the chosen publications is made through the collection and the evaluation of the front page news articles retrieved through the websites of each media outlet, respectively www.mingpao.com for Mingpao and www.thestandnews.com for StandNews. The articles may have included audiovisual elements, which formed part of the examination and were coded in the content analysis. The population for this study is composed of the whole group of news articles written in MingPao and StandNews between $1^{\text {st }}$ January 2018 and $31^{\text {st }}$ December 2020 . The choice of the front-page articles, consistently with the respective website layouts, was based on the criterion of prominence. The top five articles for each front page on any given day were selected for subsequent coding and analysis. The sample for this study is obtained through the method of the constructed week sampling, using two structured weeks to represent one year of coverage. In their study on the constructed week in the Chinese language media, Song and Chang (2012) claimed that this method is more efficient than simple random sampling or consecutive day sampling. The authors included the weekends in the count of the constructed week, an approach that this study also adopts. There is a divided opinion about the adequate number of structured weeks to effectively adopt an efficient representation of media content in the literature. Riffe, Lacy, and Fico (2014) examined past studies that utilized constructed weeks as a sampling method and highlighted there is no universal rule as to the adequate number of constructed weeks that are efficient, sufficient, and representative of the population at the same time. Some authors (e.g., Stempel, 1952) argued that two constructed weeks are sufficient for one year of 
news coverage. In their study to assess the efficiency of constructed week in daily newspapers, Riffe, Aust, and Lacy (1993), found that one constructed week adequately predicted the population mean, while two constructed weeks worked even better to infer to one year of representative content. In their work about online news, Hester and Dougall (2007) argued that two to five constructed weeks are necessary to accurately represent six months of newspaper editions. In this study, an assessment of the literature, as well as time and resource constraints, took to the negotiated choice of utilizing two structured weeks for one year of coverage, for a total of six weeks in three years, although this might be subject to change in a planned future expansion of this investigation. Using this sampling method, the total number of articles obtained is 420, 210 for Ming Pao and 210 for Standnews. The data sampled through the previously mentioned method are then analyzed using content analysis, with the individual article, comprising eventual audiovisual elements, as the unit of analysis. Two independent coders were trained and coded the articles.

Following is a brief discussion of the key variables adopted in the content analysis, while Appendices 1 and 2 include respectively the complete English and Traditional Chinese versions of the coding scheme. In case of language discrepancies between the two versions, the English language one prevailed.

\section{Measurement of Key Variables}

The coding scheme is adapted from O' Neill and Harcup (2017), Spiezio (2016), and Galtung and Ruge (1965) and includes 12 variables in total, the most analytically relevant of which, all on a nominal scale of measurement, are here discussed for explanatory purposes. 
1. EXCLUSIVITY This variable refers to stories generated by, or available first to, the news organization as a result of interviews, letters, investigations, surveys, polls, et similia.

2. SURPRISE This variable refers to stories that contain elements of surprise, contrast, or both.

3. AUDIO/VISUALS This variable refers to stories that have arresting photographs, video, audio and/or which can be illustrated with infographics.

4. TIMELINESS This variable refers to when the events took place, whether just now or however recently.

5. ENTERTAINMENT This variable refers to stories concerning sex, the show business, sport, an unfolding drama, human interest and the like.

6. FOLLOW UP This variable refers to stories whose subjects were already in the news. In other words, the events were previously covered, with new developments.

7. GOOD NEWS This variable refers to stories with particularly positive overtones, such as recoveries, breakthroughs, cures, wins, and celebrations.

8. POWER ELITE This variable refers to stories about powerful and influential individuals, organizations, institutions, and stories related to famous people in any industry (celebrity status).

9. RELEVANCE This variable refers to stories about issues, groups, nations that are perceived as being relevant to the audience for any reasons (e.g., their geographical proximity), or stories perceived as significant because of the number of people involved or affected, and (or) because of the potential impact of the events. 
10. AGENDA This variable refers to stories that set or fit the media organization's agenda (Harcup \& O’Neill, 2001).

11. COMMON MAN This variable refers to stories about ordinary people or organizations that cannot be defined as celebrities, powerful or influential.

12. BAD NEWS This variable refers to stories with particularly negative overtones, such as crimes, death, injury, defeat, conflict and loss.

\section{Intercoder Reliability}

Content analysis is a research method intended explicitly for the study of messages, and in this respect, it proved to be fundamental to mass communication research (Lombard, Snyder-Duch \& Bracken, 2002). Lombard, Snyder-Duch, and Bracken (2002, p.587) define intercoder reliability, or intercoder agreement, as "a measure of the extent to which independent judges make the same coding decisions in evaluating the characteristics of messages." Over time, various methods have been proposed in the scholarship to calculate the agreement. Riffe et al. (2014) remark that four methods are most widely used in communication research: Percent Agreement, Scott's pi, Cohen's Kappa, and Krippendorff's Alpha. This study makes use of two parameters to assess the intercoder agreement, Percent Agreement and Cohen's Kappa. Percent Agreement is a basic assessment measure to evaluate the intercoder reliability, with the caveat that it may constitute a limitation, in that Percent Agreement does not take into account chance agreement, and it may therefore overestimate the degree of reliability in the judgments (Grant, Button \& Snook, 2017). In the light of the type and nature of the variables of this study, nominal and binary, Cohen's Kappa is also employed, as a reliable parameter to assess the agreement between the coders (Grant, Button \& Snook, 2017). Both Percent Agreement and Cohen's Kappa were calculated for each variable using the freely available online tool ReCal (Freelon, 2010). 
Two coders participated in the intercoder reliability test and the subsequent coding of the sampled news items. Intercoder reliability was tested on 20 percent of randomly selected stories. Table 1 below shows the reliability coefficients calculated for each of the key variables of the content analysis. Considering a minimum threshold of reliability at 75\% (Graham, Milanowski \& Miller, 2012) for what concerns Percentage Agreement, and a minimum threshold of reliability at 0.7 for Cohen's Kappa (Hayes, 2005; 2020) - which indicates a moderate level of agreement (McHugh, 2012), the results show that all the variables reached a sufficient level of intercoder reliability, ranging from "moderate" -e.g. Entertainment- to "almost perfect" -Exclusivity(McHugh, 2012).

[Table 1 around here]

\section{Results}

Considering 420 lead stories from Citizen Journalism outlet Standnews and mainstream media outlet Mingpao, our findings show that Audiovisuals ranks at the top for Standnews (100\% of occurrence in the analyzed cases), while Timeliness ranks at the top for Mingpao (84.8\%). Table 2 shows the totals and ranking of news values (NV) identified in Mingpao and Standnews. Table 3 shows the totals, and ranking, of news values (NV) identified in Mingpao and Standnews by year.

[Table 2 around here]

[Table 3 around here]

StandNews emphasizes Audiovisuals, which indicates a routine use of multimedia elements to support the news stories, as expected from an internet-published media. Timeliness 
and News Agenda are the $2^{\text {nd }}$ and $3^{\text {rd }}$ ranked most present news values in the published articles (with respectively $89.5 \%$ and $78.1 \%$ of occurrence in the analyzed cases), which indicates that StandNews strives to keep up with the pace of the news cycle, like every other mainstream news media on the market, and that it is preoccupied with presenting its socio-political stance on the stories it publishes. Power Elite ( $74.8 \%$ of occurrence in the analyzed cases), Follow-Up $(71.9 \%)$, and Relevance $(65.7 \%)$ rank $4^{\text {th }}, 5^{\text {th }}$, and $6^{\text {th }}$ respectively, indicating a lesser yet still relevant concern for StandNews about stories that are current, relevant, and impactful on the audience, and related to the powerful people and organizations that may "make the news." Common Man (63.3\% of occurrence in the analyzed cases), and Bad News $(62.9 \%)$, ranked $7^{\text {th }}$ and $8^{\text {th }}$ respectively, are still present in a relevant number of stories, as shown in table 2 , which reveals the relative importance given by StandNews to stories with negative tones and stories that do not concern powerful entities, but ordinary people. Surprise (42.9\% of occurrence in the analyzed cases), Exclusivity (17.6\%) Entertainment (12.4\%), and Good News $(10.5 \%)$ rank $9^{\text {th }}$ to $12^{\text {th }}$ respectively on StandNews. While the news value Surprise is still present in a sizable number of stories of $42.9 \%$, Exclusivity is present only in a low number of news stories of $17.6 \%$, which arguably indicates a lack of necessary resources to research and devise exclusive news stories. Last in the rankings is Good News, which is present only in a small fraction of the news stories published by StandNews. A qualitative analysis of the text, with specific reference to Bad News and Good News, might reveal more about the type and the nature of the news stories published by StandNews, and give insight into the ability of StandNews to represent the state of affairs accurately.

MingPao emphasizes Timeliness (84.8\% of occurrence in the analyzed cases), Follow-Up $(79.0 \%)$ and Relevance $(73.8 \%)$, ranked $1^{\text {st }}, 2^{\text {nd }}$, and $3^{\text {rd }}$ respectively, which indicates the ability 
and resources to keep up with the news cycle and to publish stories that are in general current, interesting and impactful on the reader community it serves. Following are Power Elite (71.0\% of occurrence in the analyzed cases), Audio Visuals (63.8\%), and Common Man (63.3\%). Power Elite tie at $4^{\text {th }}$ place in the rankings, suggesting that, although not of primary importance, MingPao still places relative emphasis on the presence of multimedia elements to support their news stories and to stories that feature power elite entities, similarly to what StandNews does relatively to the news articles published during the analyzed period. Common Man is also present in a comparable number of stories in MingPao, suggesting that the mainstream outlet still pays attention and publishes stories that involve ordinary people and entities instead of the power elite. The fact that Power Elite and Common Man-related stories are close to each other in the rankings reasonably confirms the balanced stance and worldview of MingPao.

MingPao also gives a decided emphasis to news stories with negative tones, with $\mathrm{Bad}$ News ranked $7^{\text {th }}(51.9 \%$ of occurrence in the analyzed cases $)$, compared to positive stories, with Good News ranked $10^{\text {th }}(11.0 \%)$, which suggests the adherence to the old news adage "If it bleeds, it leads. " Interesting is that StandNews gives a similar emphasis to negative-toned stories over the positive ones, so the Citizen Journalism outlet arguably tends to adopt mainstream journalism criteria to establish newsworthiness. Surprise $(27.1 \%$ of occurrence in the analyzed cases), Exclusivity (26.2\%), and Good News rank $8^{\text {th }}$ to $10^{\text {th }}$, respectively. MingPao published a relatively low number of exclusive stories in the period analyzed in this study. While it can be argued that the mainstream outlet has more resources to research and publish exclusive stories compared to a Citizen Journalism platform, the results suggest that the mainstream outlet tends to follow and report on current affairs rather than proactively pursuing new and previously unknown stories. Which, however, requires relevant amounts of resources and appears to be a 
common trend in $21^{\text {st }}$-century mainstream journalism. Surprise and Entertainment $(4.76 \%$ of occurrence in the analyzed cases) are ranked $8^{\text {th }}$ and $11^{\text {th }}$ respectively in MingPao's adopted news values, precisely like StandNews, suggesting that the two outlets give less prominence to stories based on entertaining and surprising events, although StandNews comparably published a higher number of news stories of that nature.

\section{Discussion}

This study intended to explore and investigate the broader topic of newsworthiness - embodied by the question "what is news?" in the context of the Hong Kong media environment. The selection of two popular media outlets, MingPao and StandNews, and the subsequent analysis of their top front-page articles revealed a few aspects related to the definition and the construction of newsworthiness, which allowed to assess StandNews ability to compare and compete with mainstream media.

RQ1 and RQ2 intended to investigate the differences in news values between articles written by mainstream news outlets and Citizen Journalism, MingPao, and StandNews respectively in this study, and the possible presence of news values that are typical in either one of the analyzed outlets. The results indicate that almost all the news values considered in the investigation are present in both outlets and constitute valid criteria for selecting and publishing news articles.

Surprisingly, Audiovisuals ranks $1^{\text {st }}$ for Standnews and ranked fifth for Mingpao, suggesting that most news articles include photographs, video, audio, and infographic elements in StandNews. Citizen Journalism sites make extensive use of audiovisual elements. As described by Caple and Bednarek (2015), strong visual elements help convey and emphasize a variety of 
news factors, such as Bad News, Drama, and Surprise, thus enhancing the Shareability of the news articles to social media sites (Dick, 2014).

Timeliness is a significant factor for both news outlets, ranking second in Standnews and first in Mingpao, implying that most of the stories chosen occurred recently. Relevance is another significant factor, ranking sixth in Standnews and third in Mingpao, indicating that many stories chosen are essential to Hong Kong residents.

The third-highest news value for Standnews was News Agenda. In Hong Kong, Chinese newspapers lie on a wide political spectrum, ranging from pro-establishment to pan-democratic. Oriental Daily News and Sing Tao Daily are examples of pro-establishment newspapers, whereas the now defunct Apple Daily and Standnews are considered pan-democratic. In this respect, the stories suit Standnews' political and ideological agenda, given its pan-democratic history. However, news agendas, which in our study referred to stories that set or fit a news media's agenda, were not immediately apparent in Mingpao. While Standnews presents a fairly high number of stories motivated by that news value, compared with the total number of analyzed stories, Mingpao does not present any articles with such news value. A reasonable explanation can be found in the different socio-political stances of the two analyzed media. While Standnews has a more explicit political characterization that drives it towards issues with socio-political meaning, Mingpao has been traditionally more balanced and neutral in its stance. However, this study gives food for thought about the fact that news organizations with neutral commercial and ideological backgrounds may find it challenging to find their own agendas. Exception made for Good News that shows a decrease in recent times and News Agenda, which maintains overall a consistent level over the years, Standnews showed an increased presence of the analyzed news values in the stories from 2018 to 2020, while 
MingPao is less consistent in such increase, although maintaining high levels in the presence of the news values. An explanation can be found in the increased complexity of the published stories that may present different angles and different aspects to them, and also, for Standnews, a likely tendency to make them more newsworthy and similar in this respect to those published by the mainstream media.

Common Man surprisingly ranked $7^{\text {th }}$ for Standnews and $6^{\text {th }}$ for Mingpao. Ordinary people or organizations that cannot be defined as celebrities, powerful or influential, can also be included in the news. One example of a news story containing the news value labeled as Common Man appeared in the Standnews on 12th June 2019, interviewing an ordinary couple who went to protest in Hong Kong immediately after work. Common Man occupies a more significant proportion than Entertainment, which can be seen in Citizen Journalism outlets and mainstream media outlets. An interesting finding is that Mingpao has a higher proportion of exclusive news than Standnews, which could be explained by the fact that the Citizen Journalism publication may have fewer available resources to produce interviews, letters, investigations, surveys, and polls than mainstream media.

In contrast to Harcup and O'Neill's (2017) findings, which show that Bad News has the highest news value, this study revealed that Bad News ranked only $8^{\text {th }}$ for Standnews, even in the mainstream media Mingpao, which ranked only $7^{\text {th }}$. Furthermore, Good News is ranked 7 th out of 10 in the 2014 Harcup and O'Neill's sample, while Good News is ranked $11^{\text {th }}$ for Mingpao, indicating Good News is not as significant as 2014. Nonetheless, in both Citizen Journalism and mainstream media outlets, Bad News keeps playing a more prominent role than Good News. Out of 420 lead stories, three articles fall into both Good News and Bad News categories. One example of a story containing both Good News and Bad News appeared in the Standnews on 
22nd November 2020: “Macau GT Competition suspended! Darryl Ouyang was fined by 30 seconds, and Li Yingkin won second place". Darryl was punished for 30 seconds which is a loss (Bad News), and Li Yingkin winning second-place shows a positive overtone in the story (Good News).

Another unexpected finding is about Surprise. While Harcup and O'Neill (2017) found Surprise to be the second most important news value, our study found it to be the $9^{\text {th }}$ most important news value. Although Standnews has a higher proportion of news with a surprise, contrast, or unusual element than Mingpao, this research shows that Surprise is not a major factor in news selection compared to other news values such as Timeliness and Bad News.

To summarize, this investigation found a number of similar patterns in terms of news values identified in Mingpao and Standnews. Our study contributes to new findings of news values, such as Exclusivity and Audiovisuals, that have not been covered in previous studies.

Follow-up relates to news stories about events previously covered and that present new developments on which the media report. As a news value, Follow-up is an indication of accurate and thorough journalism, in that the news operation devotes time and resources to the developments of a story to give the audience a complete and more updated picture of the events. While this might be traditionally the realm of a mainstream operation, given the amount of time and resources necessary to follow up on developing stories, surprisingly, the results of the analysis indicate that for StandNews, Follow-up is still an important news value in the published stories, with absolute numbers comparable to those shown by MingPao, as per Table 2. This finding might again constitute an indication of the tendency to adopt, on Citizen Journalism operation StandNews, news value standards proper of mainstream media. 
The results indicate that the number of stories related to the power elite is comparably similar in the analyzed outlets, ranking $4^{\text {th }}$ in both media. While this may be expected of a mainstream operation like MingPao, it is surprising of StandNews, which devotes even more articles to the power elite than MingPao, 157 over 149, respectively. StandNews is known for taking socio-political stances on the issues on which it reports, and this might constitute a reasonable explanation as to why the Citizen Journalism outlet emphasizes Power Elite stories. A qualitative text analysis of the article might shed light on this point, notably if the analysis revealed that the stories related to the power elite published by StandNews criticize or praise the people and the institutions involved.

Both outlets give little importance to Entertainment as a news value. The stories where Entertainment is present rank $11^{\text {th }}$ out of 12 positions in both media, although StandNews still published more stories than MingPao in this respect, as per Table 2. While Entertainment is commonly a secondary topic in quality media, which may explain why MingPao does not greatly emphasize such stories, the fact that StandNews also gives less prominence to Entertainment-related stories reasonably indicates that the Citizen Journalism outlet tends to adopt mainstream standards on news values.

While Bad News is ranked 8th place in StandNews and $7^{\text {th }}$ place in Mingpao. StandNews, in the analyzed period, features a higher number of articles driven by Bad News as a value compared to MingPao, 132 to 109 respectively, as per Table 2. The emphasis given to Bad News, as mentioned before, could give indications that StandNews tends to adopt mainstream news values in the editorial decisions leading to publication, and therefore it tends to close the gap with mainstream media in terms of editorial standards. Overall, Good News does not appear to be a primary criterion that drives the publication of news articles in either outlet, while both 
StandNews and MingPao give more emphasis to stories that present negative tones. The results show that both outlets feature a similar number of articles driven by that news value, 22 and 23 respectively, as per Table 2, while MingPao gives Good News a slightly higher emphasis, ranked $10^{\text {th }}$ versus $12^{\text {th }}$ attributed to it in StandNews.

\section{Limitations and Future Directions}

Although the study allows shedding light on the construction of newsworthiness in two popular outlets in Hong Kong, it still presents some limitations that future research might address and hopefully overcome.

In terms of news values, although this study did not pay much attention to the combination of Good News and Bad News, we observed that three articles contained both Good News and Bad News, which can be helpful for future research. Also, Common Man indicates a level of significance in news selection consideration. Such news value has not been mentioned in previous quantitative news values research, and it is worth investigating further in the future through a review paper, especially for what concerns its evolution over time, as a signal of a possible change in media's understanding and representation of the roles of common people in the society.

As previously mentioned, the adoption of percent agreement as intercoder reliability coefficient presents the known limitation of not taking into account the agreement generated by chance. However, the adoption of Cohen's Kappa as a more suitable and reliable coefficient for nominal, dichotomous variables, where a series of binary judgments need to be made (Grant, Button \& Snook, 2017), allowed to overcome the limitation. Time and resource constraints led to making methodological choices that may need revision in future research. As previously discussed, the scholarship on research methods is not consistent about the sufficient number of 
structured weeks to choose to adequately represent a year of news coverage. This study used two structured weeks for each year of news coverage. However, like other studies argue (e.g., Hester \& Dougall, 2007), a higher number of weeks might be necessary for a complete representation of a year of news coverage. Another aspect to highlight is that this study is confined to the quantitative analysis of two publications in the Hong Kong media environment, and therefore the conclusions that can be inferred on the construction of newsworthiness are and remain limited to Hong Kong and the two analyzed outlets. Future research should expand the scope of the analysis, include more publications and more data points, and provide a cross-cultural, comparative perspective through the analysis of publications outside the Hong Kong media environment. Furthermore, as previously mentioned, a qualitative study is deemed necessary to move beyond the broader picture provided by the quantitative analysis and delve into the details on differences and similarities across types of journalism and across publications. We believe that a qualitative analysis along the lines of that provided by Bednarek and Caple (2017), which involves investigating the news discourse with a multimedia approach that also involves images other than written text, would provide more detailed and useful insight into how news values compare in citizen and mainstream media.

\section{Conclusion}

Still with the limitations outlined above, this study contributed to shed light on the construction of newsworthiness in two popular outlets in Hong Kong, the mainstream MingPao and the Citizen Journalism publication StandNews, identifying the most prominent criteria that drive the publication of their news articles. This analysis also allowed us to find indications of how closely Citizen Journalism follows mainstream media standards in terms of news values. In this respect, this study's results show that the playground is fairly leveled between mainstream media and 
Citizen Journalism. Therefore, at least for what concerns Hong Kong, there are indications that the output from Citizen Journalism can be considered newsworthy as that of the mainstream media. More broadly, the data suggests an evolution of Citizen Journalism in terms of adopting standards that are typical of mainstream media, thus contributing to at least narrowing the gap in terms of newsworthiness, in which quality and credibility of citizen journalism have traditionally been identified as one of the main points of criticism and distinction between Citizen Journalism and mainstream media (e.g., Dahlgren, 2016; Min, 2015).

The broader implication is that Citizen Journalism is increasingly becoming a credible force to reckon in the already ample panorama of the existing media, thus contributing to broadening pluralism for the benefit of the society. Although this might be in line with trends witnessed in other areas of the world (e.g., Mutsvairo \& Salgado, 2020), in the specific context of Hong Kong the role of Citizen Journalism is likely to remain an unfulfilled promise for the foreseeable future.

On the one hand, Citizen Journalism in Hong Kong could fulfill the promise of shedding a broader light on life events, thus contributing to shaping the mindset of a better-informed public. The success of citizen media like StandNews, has spoken for itself over the years, as previously mentioned. However, the fact that Citizen Journalism in Hong Kong is fading away following the advent of legislation that has driven the flow of information back to mainstream media at the predictable expense of alternative, non-orthodox voices has de facto defied the purpose of the role of Citizen Journalism as an alternative realm of information. Again, the parable of StandNews, which, despite its success, ended the operations at the end of 2021 after introducing new national security laws, speaks volumes in this respect (Hong Kong Free Press, 2021). 
This raises the question of what is left for Citizen Journalism and alternative media in Hong Kong. In the broader perspective of the normative theories of the media, it is plausible to argue that the only role left for Citizen Journalism, and likely for the mainstream media in Hong Kong, is what Christians et al. (2010) define as the "collaborative" function of the media. Arguably, only by collaborating with the existing centers of power and within the defined boundaries of the existing laws can alternative media, as well as mainstream outlets, survive and carry on their operations. 


\section{References}

Al-Rawi, A. (2017). News values on social media: News organizations' Facebook use. Journalism, 18(7), 871-889. https://doi.org/10.1177/1464884916636142

Avila, J. (2009). A Content Analysis of Television News Commercials. The University of Texas at San Antonio, San Antonio, TX.

Bednarek, M., \& Caple, H. (2017). The discourse of news values: How news organizations create newsworthiness. Oxford University Press

Bird, S. D. (2005). A content analysis of the most commonly adopted high school literature anthologies. University of Houston, Houston, TX. Retrieved from http://libweb.cityu.edu.hk/cgi-bin/er/db/ddcdiss.pl?3195949

Bowman, S., \& Willis, C. (2003). We media: How audiences are shaping the future of news and information. A seminal report. Reston: The Media Centre at the American Press Institute.

Burggraaff, C., \& Trilling, D. (2020). Through a different gate: An automated content analysis of how online news and print news differ. Journalism, 21(1), 112-129. https://doi.org/10.1177/1464884917716699

Burris, J. E. G. (1999). A content analysis of a sample of articles written on education in The New York Times". University of Illinois at Urbana-Champaign. Retrieved from http://libweb.cityu.edu.hk/cgi-bin/er/db/ddcdiss.pl?=9944808

Caple, H., \& Bednarek, M. (2016). Rethinking news values: What a discursive approach can tell us about the construction of news discourse and news photography. Journalism, 17(4), 435-455. https://doi.org/10.1177/1464884914568078 
Carpenter, S. (2008). How Online Citizen Journalism Publications and Online Newspapers Utilize the Objectivity Standard and Rely on External Sources. Journalism \& Mass Communication Quarterly, 85(3), 531-548. https://doi.org/10.1177/107769900808500304

Carpenter, S. (2010a). A study of journalistic and source transparency in U.S. online newspaper and online citizen journalism publications. In G. Monaghan \& S. Tunney (Eds.), Web journalism: A new form of citizenship? Eastbourne, U.K.: Sussex Academic Press.

Carpenter, S. (2010b). A study of content diversity in online citizen journalism and online newspaper articles. New Media \& Society, 12(7), 1064-1084.

https://doi.org/10.1177/1461444809348772

Centre for Communication and Public Opinion Survey, The Chinese University of Hong Kong. (2019). Public Evaluation on Media Credibility (Rep.). Retrieved from http://www.com.cuhk.edu.hk/ccpos/en/research/Credibility_Survey Results_2019 ENG.pdf

Christians, C. G., Glasser, T., McQuail, D., Nordenstreng, K., \& White, R. A. (2010). Normative theories of the media: Journalism in democratic societies. University of Illinois Press.

Chu, D. (2011). Interpreting news values in j-blogs: Case studies of journalist bloggers in post-1997 Hong Kong. Journalism, 13(3), 371-387. doi:10.1177/1464884911421576

Culig, E. A. C. (2012). A content analysis of Asian-Pacific folk songs in American elementary music textbooks from 1967 to 2008. University of Colorado at Boulder, Boulder, CO. Retrieved from http://libweb.cityu.edu.hk/cgi-bin/er/db/ddcdiss.pl?3507979

Dahlgren, P. (2016). Professional and citizen journalism: Tensions and complements. The crisis of journalism reconsidered, 247-262.

Dick, M. (2014). Interactive Infographics and News Values. Digital Journalism, 2(4), 490-506. https://doi.org/10.1080/21670811.2013.841368 
Donsbach, W. (2004). Psychology of News Decisions: Factors behind Journalists’ Professional Behavior. Journalism, 5(2), 131-157. https://doi.org/10.1177/146488490452002

Duchscher, C. J. (1998). A content analysis of three major news weekly magazines' advertisements and their use of humor. Central Missouri State University. Retrieved from http://libweb.cityu.edu.hk/cgi-bin/er/db/pqdiss.pl?1397279

Eilders, C. (1997). Nachrichtenfaktoren und Rezeption: Eine empirische Analyse zur Auswahl und Verarbeitung politischer Information [News factors and reception: An empirical analysis of the audience's selection and retention processes in political communication]. Opladen, Germany: Westdeutscher Verlag.

Eilders, C. (2006). News factors and news decisions. Theoretical and methodological advances in Germany. Communications, 31(1). doi:10.1515/commun.2006.002

Freelon, D. (2010). ReCal: Intercoder reliability calculation as a web service. International Journal of Internet Science, 5(1), 20-33.

Freelon, D. (2013). ReCal OIR: Ordinal, interval, and ratio intercoder reliability as a web service. International Journal of Internet Science, 8(1), 10-16.

Galtung, J., \& Ruge, M. H. (1965). The Structure of Foreign News: The Presentation of the Congo, Cuba and Cyprus Crises in Four Norwegian Newspapers. Journal of Peace Research, 2(1), 64-90. https://doi.org/10.1177/002234336500200104

Graham, M., Milanowski, A., \& Miller, J. (2012). Measuring and Promoting Inter-Rater Agreement of Teacher and Principal Performance Ratings. CECR. Online Submission. Grant, M. J., Button, C. M., \& Snook, B. (2016). An Evaluation of Interrater Reliability Measures on Binary Tasks Using d-Prime. Applied Psychological Measurement, 41(4), 264-276. https://doi.org/10.1177/0146621616684584 
Harcup, T., \& O’Neill, D. (2001). What Is News? Galtung and Ruge revisited. Journalism Studies, 2(2), 261-280. https://doi.org/10.1080/14616700120042114

Harcup, T., \& O’Neill, D. (2017). What is news?: News values revisited (again). Journalism Studies, 18(12), 1470-1488. https://doi.org/10.1080/1461670X.2016.1150193

Hayes, A. F. (2005; 2020). Statistical methods for communication science. ( $1^{\text {st }}$ Ed.). Routledge. https://doi.org/10.4324/9781410613707

Hermida, A. (2010). Twittering The News. Journalism Practice, 4(3), 297-308. doi:10.1080/17512781003640703

Hester, J. B., \& Dougall, E. (2007). The efficiency of constructed week sampling for content analysis of online news. Journalism \& mass communication quarterly, 84(4), 811-824. http://dx.doi.org/10.1177/107769900708400410

Hong Kong Free Press (2021). Stand news closes, content deleted following arrests and police raid; chief Sec. slams 'evil elements'. Hong Kong Free Press HKFP. Retrieved July 7, 2022, from https://hongkongfp.com/2021/12/29/breaking-stand-news-closes-website-inaccessible-follo wing-arrests-and-police-raid-chief-sec-slams-evil-elements/

Kang, I. (2016). Web 2.0, UGC, and citizen journalism: Revisiting South Korea's OhmyNews model in the age of social media. Telematics and Informatics, 33(2), 546-556. doi:10.1016/j.tele.2015.07.007

Kim, Y., \& Lowrey, W. (2014). Who are Citizen Journalists in the Social Media Environment? Digital Journalism, 3(2), 298-314. doi:10.1080/21670811.2014.930245 
Lavie, A., \& Lehman-Wilzig, S. (2003). Whose News?: Does Gender Determine the Editorial Product? European Journal of Communication, 18(1), 5-29. https://doi.org/10.1177/0267323103018001224

Lee, F. L. (2010). News Values and Resource Allocation as the Determinants of Election Coverage: Analysis of a Hong Kong Election. The International Journal of Press/Politics, 15(4), 462-481. doi:10.1177/1940161210375463

Lewis, J., Williams, A., \& Franklin, B. (2008). A compromised fourth estate?: UK news journalism, public relations and news sources. Journalism Studies, 9(1), 1-20. https://doi.org/10.1080/14616700701767974

Li, X., \& Izard, R. (2003). 9/11 Attack Coverage Reveals Similarities, Differences. Newspaper Research Journal, 24(1), 204-219. https://doi.org/10.1177/073953290302400123

Lombard, M., Snyder-Duch, J., \& Bracken, C. C. (2002). Content analysis in mass communication: Assessment and reporting of intercoder reliability. Human Communication Research, 28(4), 587-604. http://dx.doi.org/10.1111/j.1468-2958.2002.tb00826.x

McHugh, M.L. (2012). Interrater reliability: the Kappa statistic. Biochemia Medica,_22(3), 276-282. http://dx.doi.org/10.11613/BM.2012.031

Min, S. J. (2015). Conversation through journalism: Searching for organizing principles of public and citizen journalism. Journalism, 17(5), 567-582.

Mutsvairo, B., \& Salgado, S. (2020). Is citizen journalism dead? An examination of recent developments in the field. Journalism, 23(2), 354-371.

Nah, S., \& Chung, D. S. (2016). Communicative action and citizen journalism: A case study of OhmyNews in South Korea. International Journal of Communication, 10, 2297- 2317 
Nip, J. Y. (2006). Exploring The Second Phase Of Public Journalism. Journalism Studies, 7(2), 212-236. doi:10.1080/14616700500533528

O'Neill, D. (2012). No cause for celebration: the rise of celebrity news values in the British quality press. Journalism Education, 1(2), 26-44.

Paul, S. (2017). Between Participation and Autonomy: Understanding Indian citizen journalists. Journalism Practice, 12(5), 526-542. doi:10.1080/17512786.2017.1331707

Petersen, N. (1992). Asian News Values. Media Asia, 19(4), 183-189. doi:10.1080/01296612.1992.11726393

Riffe, D., Aust, C. F., \& Lacy, S. R. (1993). The effectiveness of random, consecutive day and constructed week sampling in newspaper content analysis. Journalism \& mass communication quarterly, 70(1), 133-139. http://dx.doi.org/10.1177/107769909307000115

Riffe, D., Lacy, S., \& Fico, F. (2014). Analyzing media messages: Using quantitative content analysis in research (3rd ed.). New York, NY: Routledge.

Schaudt, S., \& Carpenter, S. (2009). The news That's Fit to Click: An Analysis of Online News Values and Preferences Present in the Most-viewed Stories on azcentral.com. Southwestern Mass Communication Journal, 24(2).

Schultz, I. (2007). The Journalistic Gut Feeling. Journalism Practice, 1(2), 190-207. doi:10.1080/17512780701275507

Schulz, W. F. (1982). News Structure and People's Awareness of Political Events. Gazette (Leiden, Netherlands), 30(3), 139-153. https://doi.org/10.1177/001654928203000301 Sobhan, A. (1981). The flow of international news with special emphasis on Asia. Media Asia, 8(2), 70-74. doi:10.1080/01296612.1981.11726031 
Song, Y., \& Chang, T.K. (2012). Selecting daily newspapers for content analysis in China: A comparison of sampling methods and sample sizes. Journalism Studies, 13(3), 356-369. http://dx.doi.org/10.1080/1461670X.2011.605594

Spiezio, R. (2016). La Cina è Vicina: News Coverage and Emerging Narratives on China's Rise in Two Italian National Dailies, 1994-2013 (thesis)

Stempel, G. H. (1952). Sample size for classifying subject matter in dailies. Journalism Quarterly, 29(2), 333-334.

Wall, M. (2015). Citizen Journalism. Digital Journalism, 3(6), 797-813. doi:10.1080/21670811.2014.1002513

Welbers, K., Van Atteveldt, W., Kleinnijenhuis, J., Ruigrok, N., \& Schaper, J. (2016). News selection criteria in the digital age: Professional norms versus online audience metrics. Journalism, 17(8), 1037-1053. https://doi.org/10.1177/1464884915595474

Westerståhl, J., \& Johansson, F. (1994). Foreign News: News Values and Ideologies. In European Journal of Communication (Vol. 9, Issue 1, pp. 71-89). https://doi.org/10.1177/0267323194009001004 
Tables

Table 1

Reliability Coefficients for Key Variables

\begin{tabular}{|l|l|l|}
\hline Variable & Percent Agreement & Cohen's Kappa \\
\hline Exclusivity (NV1) & $97.8 \%$ & 0.924 \\
Surprise (NV2) & $91.1 \%$ & 0.788 \\
Audio Visuals (NV3) & $96.7 \%$ & 0.877 \\
Timeliness (NV4) & $97.8 \%$ & 0.789 \\
Entertainment (NV5) & $96.7 \%$ & 0.711 \\
Follow-up (NV6) & $94.4 \%$ & 0.863 \\
Good News (NV7) & $94.4 \%$ & 0.796 \\
Power Elite (NV8) & $88.9 \%$ & 0.726 \\
Relevance (NV9) & $94.4 \%$ & 0.887 \\
News Agenda (NV10) & $93.3 \%$ & 0.844 \\
Common Man & $88.9 \%$ & 0.772 \\
(NV11) & & \\
Bad News (NV12) & $87.8 \%$ & 0.753
\end{tabular}


Table 2

The totals, and ranking, of news values (NV) identified in Mingpao and Standnews

\begin{tabular}{|c|c|c|c|c|c|c|}
\hline News values & $\begin{array}{l}\text { Frequency } \\
\text { of news } \\
\text { values } \\
(\mathrm{NV}) \\
\text { identified } \\
\text { in } \\
\text { Standnews }\end{array}$ & $\begin{array}{l}\text { Percentag } \\
\text { e of news } \\
\text { values } \\
(\mathrm{NV}) \\
\text { identified } \\
\text { in } \\
\text { Standnews }\end{array}$ & $\begin{array}{l}\text { Ranking } \\
\text { of } \\
\text { frequenc } \\
\text { y of } \\
\text { news } \\
\text { value } \\
\text { identified } \\
\text { in } \\
\text { Standne } \\
\text { ws }\end{array}$ & $\begin{array}{l}\text { Frequency } \\
\text { of news } \\
\text { values } \\
(\mathrm{NV}) \\
\text { identified } \\
\text { in } \\
\text { Mingpao }\end{array}$ & $\begin{array}{l}\text { Percentage } \\
\text { of news } \\
\text { values } \\
\text { (NV) } \\
\text { identified } \\
\text { in } \\
\text { Mingpao }\end{array}$ & $\begin{array}{l}\text { Ranking } \\
\text { of } \\
\text { frequency } \\
\text { of news } \\
\text { value } \\
\text { identified } \\
\text { in } \\
\text { Mingpao }\end{array}$ \\
\hline $\begin{array}{l}\text { Exclusivity } \\
\text { (NV1) }\end{array}$ & 37 & $17.6 \%$ & $10^{\text {th }}$ & 55 & $26.2 \%$ & $9^{\text {th }}$ \\
\hline Surprise (NV2) & 90 & $42.9 \%$ & $9^{\text {th }}$ & 57 & $27.1 \%$ & $8^{\text {th }}$ \\
\hline $\begin{array}{l}\text { Audio Visuals } \\
\text { (NV3) }\end{array}$ & 210 & $100 \%$ & $1^{\text {st }}$ & 134 & $63.8 \%$ & $5^{\text {th }}$ \\
\hline $\begin{array}{l}\text { Timeliness } \\
\text { (NV4) }\end{array}$ & 188 & $89.5 \%$ & $2^{\text {nd }}$ & 178 & $84.8 \%$ & $1^{\text {st }}$ \\
\hline $\begin{array}{l}\text { Entertainment } \\
\text { (NV5) }\end{array}$ & 26 & $12.4 \%$ & $11^{\text {th }}$ & 10 & $4.76 \%$ & $11^{\text {th }}$ \\
\hline $\begin{array}{l}\text { Follow-up } \\
\text { (NV6) }\end{array}$ & 151 & $71.9 \%$ & $5^{\text {th }}$ & 166 & $79.0 \%$ & $2^{\text {nd }}$ \\
\hline $\begin{array}{l}\text { Good News } \\
\text { (NV7) }\end{array}$ & 22 & $10.5 \%$ & $12^{\text {th }}$ & 23 & $11.0 \%$ & $10^{\text {th }}$ \\
\hline $\begin{array}{l}\text { Power Elite } \\
\text { (NV8) }\end{array}$ & 157 & $74.8 \%$ & $4^{\text {th }}$ & 149 & $71.0 \%$ & $4^{\text {th }}$ \\
\hline $\begin{array}{l}\text { Relevance } \\
\text { (NV9) }\end{array}$ & 138 & $65.7 \%$ & $6^{\text {th }}$ & 155 & $73.8 \%$ & $3^{\text {rd }}$ \\
\hline $\begin{array}{l}\text { News Agenda } \\
\text { (NV10) }\end{array}$ & 164 & $78.1 \%$ & $3^{\text {rd }}$ & 0 & $0 \%$ & $12^{\text {th }}$ \\
\hline $\begin{array}{l}\text { Common Man } \\
\text { (NV11) }\end{array}$ & 133 & $63.3 \%$ & $7^{\text {th }}$ & 133 & $63.3 \%$ & $6^{\text {th }}$ \\
\hline $\begin{array}{l}\text { Bad News } \\
\text { (NV12) }\end{array}$ & 132 & $62.9 \%$ & $8^{\text {th }}$ & 109 & $51.9 \%$ & $7^{\text {th }}$ \\
\hline
\end{tabular}


Running head: News Values Revisited

Table 3

The totals, and ranking, of news values (NV) identified in Mingpao and Standnews by year

\begin{tabular}{|c|c|c|c|c|c|c|c|c|}
\hline News values & $\begin{array}{l}\text { Frequency } \\
\text { of news } \\
\text { values (NV) } \\
\text { identified in } \\
\text { Standnews } \\
\text { in } 2018\end{array}$ & $\begin{array}{l}\text { Frequency } \\
\text { of news } \\
\text { values (NV) } \\
\text { identified in } \\
\text { Mingpao in } \\
2018\end{array}$ & $\begin{array}{l}\text { Frequency } \\
\text { of news } \\
\text { values (NV) } \\
\text { identified in } \\
\text { Standnews } \\
\text { in } 2019\end{array}$ & $\begin{array}{l}\text { Frequency } \\
\text { of news } \\
\text { values (NV) } \\
\text { identified in } \\
\text { Mingpao in } \\
2019\end{array}$ & $\begin{array}{l}\text { Frequency } \\
\text { of news } \\
\text { values } \\
(\mathrm{NV}) \\
\text { identified } \\
\text { in } \\
\text { Standnew } \\
s \text { in } 2020\end{array}$ & $\begin{array}{l}\text { Frequenc } \\
\text { y of news } \\
\text { values } \\
(\mathrm{NV}) \\
\text { identified } \\
\text { in } \\
\text { Mingpao } \\
\text { in } 2020\end{array}$ & $\begin{array}{l}\text { Total } \\
\text { Frequenc } \\
\text { y of news } \\
\text { values } \\
\text { (NV) } \\
\text { identified } \\
\text { in } \\
\text { Standnew } \\
\text { s }\end{array}$ & $\begin{array}{l}\text { Total } \\
\text { Frequenc } \\
\text { y of news } \\
\text { values } \\
(\mathrm{NV}) \\
\text { identified } \\
\text { in } \\
\text { Mingpao }\end{array}$ \\
\hline Exclusivity (NV1) & 4 & 21 & 16 & 23 & 17 & 11 & 37 & 55 \\
\hline Surprise (NV2) & 32 & 14 & 26 & 17 & 32 & 26 & 90 & 57 \\
\hline $\begin{array}{l}\text { Audio Visuals } \\
\text { (NV3) }\end{array}$ & 70 & 51 & 70 & 46 & 70 & 37 & 210 & 134 \\
\hline Timeliness (NV4) & 68 & 61 & 61 & 58 & 59 & 59 & 188 & 178 \\
\hline $\begin{array}{l}\text { Entertainment } \\
\text { (NV5) }\end{array}$ & 10 & 7 & 8 & 2 & 8 & 1 & 26 & 10 \\
\hline Follow-up (NV6) & 41 & 55 & 54 & 61 & 56 & 50 & 151 & 166 \\
\hline Good News (NV7) & 6 & 13 & 10 & 1 & 6 & 9 & 22 & 23 \\
\hline Power Elite (NV8) & 51 & 48 & 50 & 48 & 56 & 53 & 157 & 149 \\
\hline Relevance (NV9) & 38 & 39 & 45 & 56 & 55 & 60 & 138 & 155 \\
\hline $\begin{array}{l}\text { News Agenda } \\
\text { (NV10) }\end{array}$ & 44 & 0 & 62 & 0 & 58 & 0 & 164 & 0 \\
\hline $\begin{array}{l}\text { Common Man } \\
\text { (NV11) }\end{array}$ & 40 & 40 & 51 & 50 & 42 & 43 & 133 & 133 \\
\hline Bad News (NV12) & 40 & 25 & 43 & 39 & 49 & 45 & 132 & 109 \\
\hline $\begin{array}{l}\text { Total number of } \\
\text { news stories }\end{array}$ & 70 & 70 & 70 & 70 & 70 & 70 & 210 & 210 \\
\hline
\end{tabular}

